\title{
The Determinants Influencing the Performance of Women Entrepreneurs in Malaysia: A Conceptual Framework
}

\author{
DOROTHY CHIPFUNDE, SITI NORBAYA YAHAYA*, NORFARIDATUL AKMALIAH OTHMAN \\ FACULTY of TECHNOLOGY MANAGEMENT AND TECHNOPRENEURSHIP, UNIVERSITI TEKNIKAL MALAYSIA \\ MELAKA, MALAYSIA. *E-mail: sitinorbaya@utem.edu.my
}

\begin{abstract}
There is no doubt that the number of women entrepreneurs continues to increase globally. Women entrepreneurs in Malaysia are experiencing a drastic decline in performance and result in shutting down business ventures. The purpose of this study examined the factors affecting the performance of women entrepreneurship in Malaysia. The phenomenal growth of women entrepreneurs and the gap in the current performance literature have necessitated this study. Due to lack of individual characteristics, inadequate family support, access to loan and finance, gender inequality, and mentorship has created huge challenges in Malaysia SMEs for women entrepreneurs and this has created a performance's reduction of women entrepreneurs. The expected results will help to affirm the relationship between individual characteristics, family support, access to loan and finance, gender inequality, lack of mentorship, and women entrepreneurs' performance. This study would help women entrepreneur to create platforms to increase performance, improve the management skills, strategize easy ways to access loan and finance, build a strong tie for family support, create job opportunities as well as promote the economy of Malaysia.
\end{abstract}

Keywords: Women Entrepreneurs, Performance, SME's.

JEL Classification: M19 


\section{Introduction}

One of the major challenges for women entrepreneur's performance in Malaysia SME's has been focused on the individual characteristics, inadequate family support, access to loan and finance, gender inequality, and lack of mentorship, and which has gradually reduced the overall performance of SME's in Malaysia (Filzah et al., 2019). Various studies have agreed that access to loan and finance has an influence on women entrepreneur's performance as well as creating job opportunities effectively. Management skills and family support have a relationship with performance and these factors are required for further improvement, to promote women entrepreneur's performance and productivity effectively (Shamsul and Norashidah, 2017). Lu, Zhu, and Bao (2015) agreed that the organisational performance change model has strengthened the influences of women entrepreneur's performance within SME's. The figure, 1.1, depicted that the total number of SMEs was 907,065, and 187,000 are women entrepreneurs, which consist of $20.6 \%$ and this further confirmed that the women entrepreneurs are decline as well as shutting down their business ventures. Also, the performance of women entrepreneur's in Malaysia amongst service, manufacturing, construction, agriculture and mining \& quarrying sectors of SME's showed that there is an increase from 2015 (9.7\%) to 2017 (25.9\%), and a drastic decline in performance from 2017 (25.9\%) to 2019 (11.6\%), which was the reason behinds this study. In 2019, SME's contributes 38.3\% of Malaysia's GDP to boost the economy effectively (Malaysia SME Corporation, 2019). However, this drastic decline was a result of poor individual characteristics, inadequate family support, limited access to loan and finance, gender inequality, and lack of mentorship and which reduce the overall women entrepreneur's performance.

Figure 1.1: SME Corporation Malaysia - SME Statistics Report in 2019

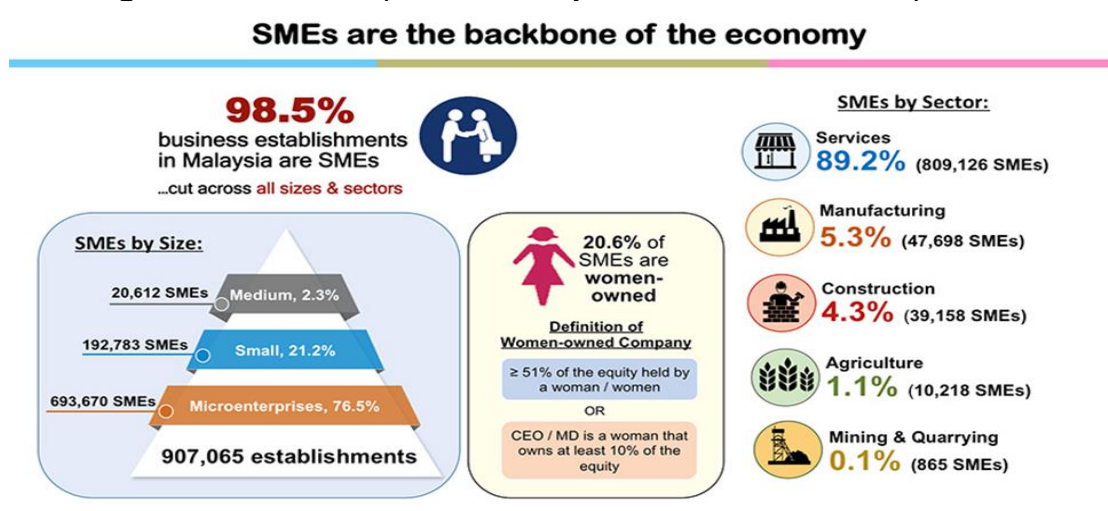

Figure, 1.2, depicted that SMEs contribute heavily to the development of the Malaysian economy. The GDP contributed by SME's was $32.5 \%$ of the Malaysian economy. SME's account for $98.5 \%$ of businesses in Malaysia and which consist of $75 \%$ of micro, $19 \%$ of small, and $3 \%$ of medium companies and which gives the 662,939 in 2017 (Malaysia SME Corporation, 2017). Furthermore, it showed that there is an increase from 2017 (figure 1.2) to 2019 (figure 1.1).

Figure 1.2: SME Corporation Malaysia - SME Statistics Report in 2017

\begin{tabular}{l} 
- SMEs account for large proportion of businesses in Malaysia: \\
$-98.5 \%$ of establishments \\
- Size wise $77 \%$ microenterprises, with < 5 workers \\
\hline
\end{tabular}

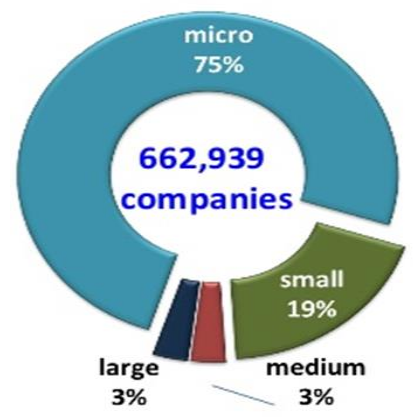

SME contribution to:

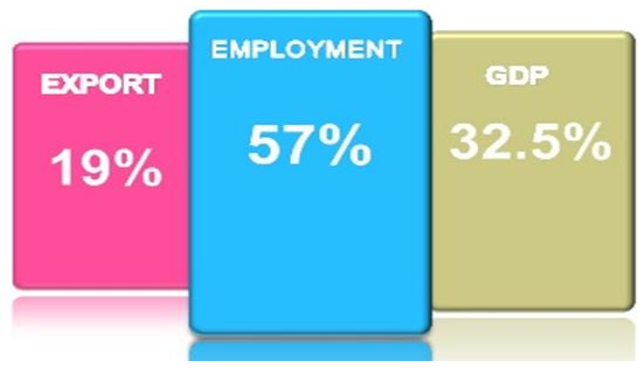


Women entrepreneurs are vital to the economic growth of most countries, including Malaysia (Isa, Jaganathan, Afiq, and Ahmdon, 2019). This is because women's involvement in entrepreneur is significant in transforming and empowering society through innovation, job creation, alleviation of poverty, tax payment, and prosperity formation in all economies (Edona, 2015). More than $52 \%$ of the world's women entrepreneur population started up new businesses in various fields in 2010 and the figure representing an additional 83 million women who had launched their business at least three and a half years. In line with this, access of women to entrepreneurial ventures is widened in most countries, especially in sectors previously dominated by men (Kanapathipillai and Azam, 2019). SME's in Malaysia have experienced sudden, unexpected low performance in term of women entrepreneur's due to various challenges such as lack of individual characteristics, inadequate family support, access to loan and financial support, gender inequality, and lack of mentorship and this has created a performance's reduction of women entrepreneurs from 2017 (25.9\%) to 2019 (11.6\%) (Malaysia SME Corporation, 2019). Women entrepreneur's in Malaysia experienced low performance in the past two (2) years, which was as a result of lack of management skills, limited access to loan and financial support, and inadequate family support, and these factors contributed heavily towards the low women entrepreneur's performance in Malaysia SME's (Saidi, Rashid, Ramlan and Johari, 2017).

Figure 1.3 depicted that women entrepreneur's performance in SME's sector are decreasingly in term of performance, and this issue hinders the economic growth of Malaysia as well as the SME's sector. This further elaborated that there is an increase in the women entrepreneur's performance from 2015 (9.7\%) to 2017 (25.9\%) due to several NGO support to most women entrepreneurs to boost their business ventures as well as promote more job opportunities for employees and enhance women entrepreneur's performance. However, the decline in performance from 2017 (25.9\%) to 2019 (11.6\%) was due to poor individual characteristics, lack of financial support, family support, gender inequity amongst SME's investors, and mentorship (Malaysia SME Corporation, 2019). These were the factors that influence the women entrepreneur's performance in the SME's sectors in Malaysia as shown in figure 1.3 below.

Figure 1.3: Malaysia Statistics Report for SME's Corporation for 2019

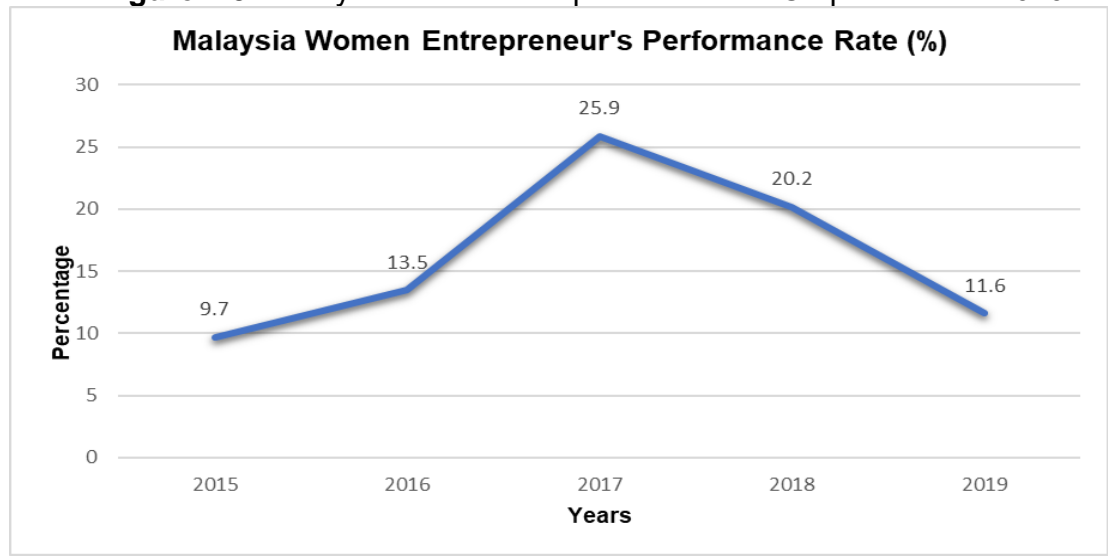

The women entrepreneur's performance in Malaysia have suffered drastic low performance and which affected the growth rate of most women-owned business ventures in 2019. In Malaysia, SME's contributes $38.3 \%$ of GDP, $98.5 \%$ of business ventures are owned by SMEs, and women entrepreneurs contribute $20.6 \%$ of the business. Women entrepreneurs' are not encouraged, supported, and financed to promote their skills and strategies towards Malaysia's development, and these issues are hindrances due to lack of cultural values for gender equity in terms of a business venture and lack of family support decline women entrepreneurs towards performance. According to Shamsul and Norashidah, (2017) asserted that a lack of family support reduces women's commitment towards providing an edge for greater business growth. A study conducted by Siba, (2019) agreed that access to loans and finance has a strong effect on women entrepreneur's performance. He further elaborates that due to gender inequity, men are considered with much access to loans and which promote men entrepreneur's performance in Malaysia. According to Fuentes-Fuentes, Bojica, Ruizarroyo, and 
Welter, (2017) believed a lack of mentoring will drastically affect the performance of women entrepreneurs. Women entrepreneurs suffer as a result of gender inequity both in terms of access to loans, government policy provision, and family support.

As the research gap of this study, the researcher adopted management skills, family support, and access to a loan to comprehend the women entrepreneur's performance in SME's sector in Malaysia. Halim, Ahmad, Ramayah and Hanifah, (2014) agreed that poor management skills, family support, and access to the loan have been identified as one of the problems that affect the performance of women entrepreneurs amongst SMEs in Malaysia. Entrepreneurs were unable to perform well as a result of these challenges and these leads to low productivity as well as women entrepreneur's performance (Assefa and Cheru, 2018). Various past research has studied the relationships of mentoring, family support, and access to loans, but further research is required to be conducted in the Malaysian SME's sector (Adibah, 2015). A large amount of literature available for different antecedents on women entrepreneurs' performance, but little empirical research has been studied on the determinants factors affecting the performance of women entrepreneurship in Malaysia SME's sector. However, these issues lead to this study objective, and which focused as follows; (1) identify the factors affecting the performance of women entrepreneurs in Malaysia. (2) to evaluate the relationship between determinant factors towards the performance of women entrepreneurs in Malaysia. (3) to determine the most influencing factor affecting the performance of the women entrepreneurs in Malaysia.

\section{Literature Review}

\subsection{Performance of Women Entrepreneur in Malaysia}

Although performance is one of the most sought out in organizational context, it is yet an elusive research subject since the early development of organizational theory. Therefore, there exist several definitions of the construct. For example, Ibrahim, Mahmood, and Bakar, (2016) defined performance as a term that illustrates the ability to meet pre-determined goals or objectives while Ayub et al., (2013) considers performance as the results of a person or a company compared to its intended outputs. However, Hasan and Almubarak, (2016) defined performance as the actual results or output of an individual or a company as measured against the intended outputs or goals and objectives. According to Zeb, Jan, Ihsan, and Shah (2019), performance is measured with three indicators related to the specific areas of firm outcomes and the multidimensional constructs are financial performance, product market performance, and shareholder returns. The financial performance is measured with items such as profit margin, return on assets, and return on investment while product market performance is measured with sales and market share (Sharma, Davcik and Pillai, 2016). However, the shareholder return dimension is measured by total shareholder return and economic value added (Saad, Ali and Guza, 2018).

\subsection{Determinants Influencing Women Entrepreneurs Performance}

\subsubsection{Individual Characteristics}

Individual characteristics are known as personal traits such as inner drive, motives, goals or aspirations, qualifications and experiences, and other intrinsic attributes that are relevant to successfully start and run a business venture (Bouzekraoui and Ferhane, 2017). Individual characteristics play a significant role in starting and successfully running an entrepreneurial venture. For example, individuals with openness traits are curious, sensitive, and open to emotions and they are ready to always try new things. Thus, open-minded people are more creative than closed-minded people because their curious mind makes them seek knowledge and constantly learn new things (Abdullahi, Abubakar, Aliyu, and Umar, 2015). However, people with high openness are more likely to hold unconventional beliefs. As a result, they lack focus, engage in risky behaviours, or are perceived as unpredictability. However, individuals who have low openness ability tend to gain personal or professional fulfillment using perseverance and pragmatic, data-driven, and even dogmatic as well as 
the closed-minded approach (Chinomona, 2013). Also, women who are extroverts like to interact with other people and share ideas because they are full of energy. Extroverts are action-oriented people, and they are enthusiastic about meeting new people, talking to them, and making new friends (Kain \& Sharma, 2013). However, introverts tend to have lower social engagement than extroverts because introverts are quiet, maintain low key, and are less engaged in social activities (Eniola, Entebang, and Sakariyau, 2015). Evidence indicates that individual characteristics influence one's entrepreneurial performance. A study conducted by Mari, Poggesi, and Vita, (2016) found that individual characteristics such as the entrepreneurs' goals and motives, networking, and entrepreneurial orientation serve as key determinants influencing business performance. Also, a study conducted by Gaganis, Pasiouras and Voulgari, (2019) reveals that women's attitudes towards entrepreneurship are part of the business environment and these also have immense significance for female entrepreneurs' performance. Moreover, the study of Atef and Al-Balushi, (2015) asserts that women's social views and opinions can either encourage or discourage women entrepreneurs and these factors inhibit entrepreneurial performance. However, it is pointed out by Kallas (2019) that the extent to which female entrepreneurs undergo structural barriers negatively influences the performance of their ventures.

\subsubsection{Family Support}

Family support is known as the emotional, operational, and financial assistance received by women entrepreneurs from their loved ones or family members (Naidu \& Chand, 2017). The amount of emotional, operational, and financial support a female entrepreneur receives from her husband, family members, and/or friends will determine the level of involvement in entrepreneurial activities and the success achieved in her entrepreneurial venture (Kim and Gao, 2013). This is because starting and building a business into a successful one requires emotional and operational support and advice as well as financial assistance from other experienced people. For example, lack of access to finance and other credit facilities has been attributed to the low involvement of women as entrepreneurs in several poor and developing nations, where inequality treatment between men and women exists (Phonthanukitithaworn, Ketkaew, and Naruetharadhol, 2019). The opportunity to get capital facilities are restricted to women entrepreneurs as found in several countries and this affects their business performance (Rajan, Muralidharan and Ravi, 2019). As a result, family support in terms of financial assistance is vital to starting and successfully running a business. Furthermore, women are traditionally less expected to perform entrepreneurial roles in some countries (Saks and Burke-Smalley, 2014). For example, many Muslim countries consider women to be dishonoring her husband by stepping into the business. According to Yusuf, Azizi, and Shuhymee (2016), a woman needs to seek her husband's consent to take a job or start a business in Iran. The structural barriers that women can face have a major impact on the performance of their ventures. This means that the woman's ability to obtain her husband's consent and support would enhance her success in an entrepreneurial venture. Studies in women entrepreneurs in Malaysia revealed that family support and relationship with others in society are the important factors that influence their business success (Gorondutse, Ibrahim, Abdullwahab and Naalah, 2018). However, another study conducted by Prasad, Naidu, Murthy, Winkel, and Ehrhardt (2013) found that parental influence is the key determinant influencing business performance among women entrepreneurs. This is because parents do not only influence the career path of their children but can also provide the emotional, operational, and financial support needed to start and succeed in the world of entrepreneurship.

\subsubsection{Access to Loans and Financial Support}

As described by Huhtala et al., (2014) "According to International Finance Commission (IFC, 2007), a female entrepreneur starts their business with a lower level of capital and a small percentage of debts finances compared to male entrepreneurs. They also lack access to loans". The effect of this is those male counterparts are also given high consideration when it comes to financial assistance and loan and due to this, performance is limited or constrained to a limit. This is further confirmed by 
Kamunyu and Theuri, (2017) "Women were found to have the perception that they were disadvantaged due to their gender and could not easily manage businesses as opposed to their male counterparts". This is one of another such kind of factors that deprives women entrepreneur of fulfilling their dreams to become an entrepreneur. This is because it has increasingly difficult for women to get or have access to loans and finance from financial institutions across the country. This happens as a result of a male entrepreneur is preferred more than a female entrepreneur and because of this are given better consideration especially when it comes to loans and financing business projects. Another consideration that also plays a significant role here is gender as it has become a norm that women are naturally disadvantaged and because of this much considerations are not given to women when it comes to giving loans and financial support (Manoj et al., 2013). In the case where these women have access to loans and financial support, they don't get as much as compared to their male competitors, no matter how promising the business the loans would be used finance looks or sounds like. The issue of not having access to loans and financial support has always been a recurring issue. It's simple, an entrepreneur that has access to the right amount of loan and financial support has a higher chance of being successful than one that doesn't have the right amount of loan and financial support or doesn't have at all (Sitharam and Hoque, 2016). Performance is improved when an entrepreneur has the right amount of loan or financial support to foster business processes, make strategic changes, and put in places, business processes that enhance the business (Nasri and Muhammad, 2018). An entrepreneur will always need loans or financial support especially at the initial stage of starting the business because this is the point where the business is most vulnerable (Welsh, Kaciak and Shamah, 2018).

\subsubsection{Gender Inequality}

As explained by Gudiene, Banaitis, Lopes, and Banaitiene, (2013) "Gender disparities impact women negatively, limit their entrepreneurial activities and depress economic growth. Researchers have argued that cultural values deeply affect entrepreneurship and economic development.". Further revelation shows that "Culture affects the entrepreneurial process and interpretation of opportunities". As described by Satta, Parola, Penco, and De Falco, (2016) "In terms of loans and funds accessibility, women face challenges accessing compared to a male". Further explanations revealed that "women entrepreneurs may be relatively less well represented among entrepreneurs but better represented in growth-oriented forms of entrepreneurship". This means that more considerations are given more to men than women especially when it comes to financial assistance or loans from financial institutions. This is another factor that affects the performance of women entrepreneur and this also integrates other factors away (Armagan, 2013). Cultural values as explained earlier has a norm that culturally, women are supposed to found at home, taking care of the family, and attending to family needs (Sweida and Reichard, 2013). This has become a hindrance and affects the performance of women entrepreneur because the gender factor is taken into consideration and that men are stronger and better than women and so men should be the one going out to work while women stay home to take care of the home and all that concerns it (Soysal, 2013). A closer examination of access to loans and financial support also hinder the performance of women entrepreneur in the sense that it has increasingly difficult for women to get or have access to loans and finance from the financial institutions across the country based on the fact that male entrepreneur is preferred more than female entrepreneur and because of this are given better consideration especially when it comes loans and financing business projects (Grissemann, Plank and Brunner-Sperdin, 2013). Researchers have argued that cultural values deeply affect entrepreneurship and economic development. Furthermore, according to cultural value, women are supposed to found at home, taking care of the family, and attending to family needs (Agarwal, Lenka, and Agrawal, 2016).

\subsubsection{Mentorship}

Mentorship is very similar to motivation but plays different roles. As explained by Powell and Eddleston, (2013) referring as "mentoring supports and encourages people to manage their learning 
resulting in maximizing their potential, by developing skills, improving their performance, and becoming the person they want to be". Further explanations, referring to Nikina, Shelton, and LeLoarne, (2015) said: "an interactive process occurring between individuals of differing levels of experience and expertise that incorporate interpersonal or psychosocial development, career, and/or educational development, and socialization functions into their relationship". The importance of mentorship cannot be overemphasized as it is important a young woman entrepreneur knows exactly what she is going into, have a full understanding of what to expect which enables her to prepare for in case things do not work out the way it has been planned. This can only be achieved if the young entrepreneur has a mentor who can help her build on her instincts, skills, and initiative to build a strong and durable business (Sebikari, 2014). This is very similar to that of motivation and as explained earlier One of the greatest factors that also impact women entrepreneur in Malaysia is the fact that most of them don't have any mentor or when they have a mentor, such mentors are not fully committed to them and so practically don't gain anything whatsoever and so hardly perform beyond a level even though they have the required skills, management skills and knowledge of how to run a successful business. Another twist to this is that, where the young entrepreneur has a committed mentor, her skills and initiatives can be improved over time which enhances the level of her performance and eventually transforms into business success which is the ultimate goal of being an entrepreneur to become successful (Leszczyński, 2016).

\subsection{Conceptual Framework}

Figure 1.4: Conceptual Framework

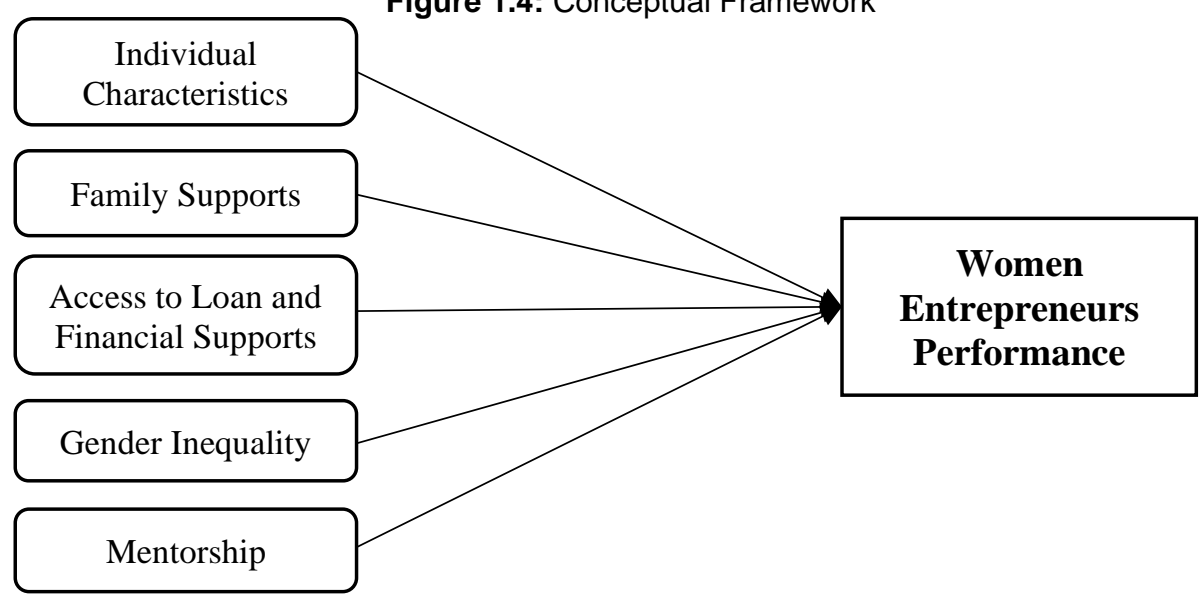

\section{Research Methodology}

This study will be carried out by conducting various reviews of academic journals and extensive literature related to the women entrepreneur's performance in Malaysia. Articles from past studies were analysed and evaluated using the process of a systematic review that was used on the previous studies related to this study. By adopting the use of three steps which includes: planning to conduct and reporting of the previous reviews. The preliminary step focuses on the planning review that was derived earlier in the introduction that argues on the background of the study, challenges, and objectives of this paper. The second step will be focusing on the extensive review of acceptable and recognised journal related to the determinants that influence women entrepreneur's performance in Malaysia.

Among the database that is widely referred are:

1. ProQuest

2. Scopus.

3. Elsevier Science Direct.

4. Emerald Management Extra Plus. 
However, to monitor through massive pools of documents in the database, the use of main keywords was adopted as it helps to group the vital and present words in an abstract of an article. The first keyword used is a women entrepreneur. The second keyword is on "performance". And third combination keyword, which we search for, is 'the determinants of women entrepreneurs performance". The search leads to numerous journal articles then are further examined to suit the standard of this study. Lastly, weak articles were rejected from further used in this analysis, as they do not make any reference to women entrepreneurs but focusing on women entrepreneur's performance.

\section{Conclusion}

There is no doubt that women entrepreneurs in Malaysia have increased over the years to the point where their contribution cannot be ignored anymore. However, when their respective performance is evaluated and compared with their male counterpart, the achievements have a wide gap. This study has confirmed that individual characteristics, family support, access to loan and financial support, gender inequity and mentoring have a significant influence on women entrepreneur's performance in Malaysia. However, various factors that affect them which have over the years lowered or limited their respective performance. Furthermore, this study must identify and evaluate the factors that affect the performance of women entrepreneurs in Malaysia. The conceptual framework was helpful to provide desirable solutions to the issues associated with women entrepreneur performance. This study will help to bridge the gap, provide awareness of access to loan and finance, improve decision-making, problem-solving skills as well as promote the GDP of Malaysia economy effectively. The expected results would help to increase the women entrepreneur's characteristics, advance family support, increase the rate of the loan and financial support accessibility, minimise the level of gender inequality and promote mentorship and which would reflect positively towards the development of women entrepreneur's performance in Malaysia.

\section{References}

1. Abdissa, G., \& Fitwi, T. (2016). Factors Affecting Performance of Micro and Small Enterprises in South West Ethiopia: The Case of Bench Maji, Sheka, and Kefa Zones. Global Journal of Management and Business Research: Administration and Management, 16(10), 13-27.

2. Abdullahi, M. S., Abubakar, A., Aliyu, R. L., \& Umar, M. B. (2015). Empirical Review on the Determinants Influencing Firm Performance in Developing Countries. International Journal of Scientific and Research Publications, 5(6), 52-64.

3. Agarwal, S. \& Lenka, U. (2015). Study on Work-life Balance of Women Entrepreneurs; Review and Research Agenda. Industrial and Commercial Training, 47(7), 356-362.

4. Agarwal, S., \& Lenka, U., (2016). An Exploratory Study on the Development of Women Entrepreneurs: Indian Cases. Journal of Research in Marketing and Entrepreneurship, 18(2), 232247.

5. Agarwal, S., Lenka, U. \& Agrawal, V. (2016). An Empirical Investigation of Self-Confidence of Indian Women Entrepreneurs, in Pillania, R.K., Bhandari, N. and Dasgupta, M. (Eds), Emerging Themes in Strategy, Mc Graw Hill Education, New Delhi, pp. 104-115.

6. Al-kwifi, O. S., Khoa, T. T., Ongsakul, V., Ahmed, Z. U., Sam, O., Khoa, T. T \& Ahmed, Z. U. (2019). Determinants of Female Entrepreneurship Success across Saudi Arabia Determinants of Female Entrepreneurship Success. Journal of Transnational Management, 1(1), 1-27.

7. Al-Tit, A., Omri, A., \& Euchi, J. (2019). Critical Success Factors of Small and Medium-sized Enterprises in Saudi Arabia: Insights from Sustainability Perspective. Administrative Sciences, 9(2), 32-43.

8. Armagan A (2013). The relationship between Entrepreneurship and Autonomy: An Investigation on the Students of the communication faculty of the Agean University. International Periodical for the Languages, Literature, and History of Turkish or Turkic, 8(12), 49-69. 
9. Assefa, M., \& Cheru, E. (2018). Factors Affecting the Growth of Women Entrepreneurs in Micro and Small Enterprises in Ethiopia. Abyssinia Journal of Business and Social Sciences, 3(1), 32-38.

10.Atef, T. M., \& Al-Balushi, M. (2015). Entrepreneurship as a Means for Restructuring Employment Patterns. Tourism and Hospitality Research, 1(5), 73-90.

11.Ayub.A., Aslam.M.S., Razzaq.A., \& Iftekhar.H. (2013). Gender Effects on Entrepreneurial Orientation and Value Innovation: Evidence from Pakistan. European Journal of Business and Social Science, 2(1), 82-90.

12.Bakar, A. A., \& Ahmad, S. (2016). Determinant Factors of Women Entrepreneurs' Business Performance: A Conceptual Framework. Journal of Global Business and Social Entrepreneurship (GBSE), 1(1), 55-67.

13.Bhardwaj, B.R., (2014). Impact of Education and Training on Performance of Women Entrepreneurs: A Study in Emerging Market Context. Journal of Entrepreneurship in Emerging Economies, 6(1), 3852.

14.Bouzekraoui, H., \& Ferhane, D. (2017). An Exploratory Study of Women's Entrepreneurship in Morocco. Journal of Entrepreneurship: Research \& Practice, 2(1), 47-61.

15.Ceptureanu S I, \& Ceptureanu E G. (2016). Women Entrepreneurship in Romania: The Case of North East Development Region. Manag. Econ. Rev. 1(1), 20-32.

16.Chatterjee, S., Dutta Gupta, S., \& Upadhyay, P. (2018). Empowering Women and Stimulating Development at Bottom of Pyramid through Micro-entrepreneurship. Management Decision, 56(1), 160-174.

17.Cheraghi, M., (2013). Innovation by Entrepreneurs in China: The Increasing Prominence of Women. Journal of Knowledge-based Innovation in China, 2(3), 172-187.

18.Chinomona, R. (2013). Business Owner's Expertise, Employee Skills Training, and Business Performance: A Small Business Perspective. Journal of Applied Business Research, 29(6), 1883.

19.Cho, J., Miller, D., \& Lee, J. (2018). Too much of a Good thing: Family Involvement and the Survival of Listed Korean Firms. Journal of Family Business Strategy, 9(1), 223-237.

20.Chowdhury, M., Alam, Z. \& Arif, I. (2013). Success Factors of Entrepreneurs of Small and Mediumsized Enterprises: Evidence from Bangladesh. Macro Think Institute, 3(2), 38-53.

21.Ekpe, I. Razak, R. C., Ismail, M., \& Abdullah, Z. (2016). Entrepreneurial Skill Acquisition, PsychoSocial Factors, and Youth's Self-Employment in Malaysia. Journal of Entrepreneurship Education, 19(2), 93-101.

22.Eniola AA, Entebang H, \& Sakariyau O B (2015). Small and Medium Scale Business Performance in Nigeria: Challenges faced from an intellectual capital perspective. Int. J. Res. Stud. Manag. 4(1), 5971.

23.Eniola Anthony Abiodun \& Dada Duro Amos (2018). The Performance of Women Entrepreneurs: Human and Financial Capital. Triple-A Research Journal of Social Science and Humanity, 2(1), 30-37.

24.Fatima, H., \& Muneer, A. (2018). Factors Influencing Women Entrepreneurs' Performance in SMEs. World Journal of Entrepreneurship, Management, and Sustainable Development, 12(2), 82-101.

25.Fayolle, A., \& Liñán, F. (2014). The Future of Research on Entrepreneurial Intentions. Journal of Business Research, 6(7), 663-666.

26.Fuentes-Fuentes, M. D. M., Bojica, A. M., Ruizarroyo, M., \& Welter, F. (2017). Innovativeness and Business relationships in Women-owned Firms: The Role of Gender Stereotypes. Canadian Journal of Administrative Sciences/revue Canadienne des Sciences de I Administration, 3(4), 63-76.

27.Gadi P D, Tende SB, \& Barde B (2014). The Effect of Human Capital Development on the Performance of Small and Medium Family Enterprises in Nigeria. Global J. Bus. Admin. Manag. 2(1), 1-14.

28.Gaganis, C., Pasiouras, F., \& Voulgari, F. (2019). Culture, Business Environment, and SMEs' Profitability: Evidence from European Countries. Economic Modelling, 7(8), 275-292.

29. Georgiadis, A., \& Pitelis, C. N. (2016). The Impact of Employees' and Managers' Training on the Performance of Small-and Medium-Sized Enterprises: Evidence from a Randomized Natural Experiment in the UK Service Sector. British Journal of Industrial Relations, 54(2), 409-421. 
30.Gonzalez-Rodriguez, M. R., Jimenezcaballero, J. L., Martinsamper, R., Koseoglu, M. A., \& Okumus, F. (2018). Revisiting the Link between Business Strategy and Performance: Evidence from Hotels. International Journal of Hospitality Management, 7(2), 21-31.

31.Gorondutse, A.H., Ibrahim, G., Abdullwahab, H.I. \& Naalah, M.N.I., (2018). Founder's Syndrome and Firm Performance of Small and Medium Scale Enterprises in Nigeria. Journal of Health Management and Informatics, 5(1), 1-8.

32.Gudiene, N., Banaitis, A., Lopes, J., \& Banaitiene, N. (2013). Development of a Conceptual Critical Success Factors Model for Construction Projects: A Case of Lithuania. Procedia Engineering, 5(7), 392-397.

33.Gupta, N., \& Mirchandani, A. (2018). Investigating Entrepreneurial Success Factors of Womenowned SMEs in UAE. Management Decision, 56(1), 219-232.

34.Grissemann, U., Plank, A., \& Brunner-Sperdin, A. (2013). Enhancing Business Performance of Hotels: The Role of Innovation and Customer Orientation. International Journal of Hospitality Management, 3(3), 347-356.

35. Halim, H. A., Ahmad, N. H., Ramayah, T., \& Hanifah, H. (2014). The Growth of Innovative Performance Among SME's: Leveraging on Organisational Culture and Innovative Human Capital. Journal of Small Business and Entrepreneurship Development, 2(1), 107-125.

36. Hameed, W. U., Hussin, T., Azeem, M., Arif, M., \& Basheer, M. F. (2017). Combination of Microcredit and Micro-Training with Mediating Role of Formal Education: A Micro-Enterprise Success Formula. Journal of Business and Social Review in Emerging Economies, 3(2), 285-291.

37.Hampel-Milagrosa, A., Loewe, M., \& Reeg, C. (2015). The Entrepreneur makes a difference: Evidence on MSE Upgrading Factors from Egypt, India, and the Philippines. World Development, 6(6), 118-130.

38.Hasan, F.S.M.A. \& Almubarak, M.M.S. (2016). Factors Influencing Women Entrepreneurs' Performance in SMEs. World Journal of Entrepreneurship, Management, and Sustainable Development, 12(2), 82-101.

39. Hemalatha M, Mohan V C, \& Jasim K M (2013). The Antecedents of Marketing success of women entrepreneurs. Int. J. Bus. Innovation Res. 7(6), 637-662.

40.Henry, C., \& Kennedy, S. (2017). In Search of a New Celtic Tiger: Female Entrepreneurship in Ireland. In Buttler, J. E. (Ed.), New Perspectives on Women Entrepreneurship: A Volume in Research in Entrepreneurship and Management, 203-225.

41. Huhtala, J. P., Sihvonen, A., Frösén, J., Jaakkola, M., \& Tikkanen, H. (2014). Market Orientation, Innovation Capability, and Business Performance: Insights from The Global Financial Crisis. Baltic Journal of Management, 9(2), 134-152.

42.Ibrahim, N., Mahmood, R., \& Bakar, M. (2016). Linking Strategic Improvisation and Entrepreneurial Self-Efficacy to Corporate Entrepreneurship in Nigerian Higher Education Institutions (HEls). Management Science Letters, 6(12), 742-752.

43.Isa, F., Jaganathan, M., Afiq, M., \& Ahmdon, S. (2019). Malaysian Women Entrepreneurs: Some Emerging Issues and Challenges of Entering Global Market Malaysian Women Entrepreneurs: Some Emerging Issues and Challenges of Entering Global Market. International Journal of Academic Research in Business and Social Sciences, 8(12), 701-719.

44.Ismail V. Y (2014). The Comparison of Entrepreneurial Competency in Woman Micro-, Small-, and Medium-scale. Entrepreneurs Procedia - Social and Behavioural Sciences, 11(5), 175-187.

45.Jha, P., \& Makkad, M. (2018). Performance-oriented Factors for Women Entrepreneurs - A Scale Development Perspective. Journal of Entrepreneurship in Emerging Economies, 10(2), 329-360.

46.Kain P, \& Sharma M (2013). Women Entrepreneurship Education need for Today. Journal of Management Sciences and Technology, 1(1), 43-53.

47.Kallas, E. (2019). Environment-readiness Entrepreneurship Intention Model: The Case of Estonians and the Russian-speaking Minority in Estonia. SAGE Open, 9(1), 125-134.

48.Kamunge, M. S., \& Tirimba, O. I. (2014). Factors Affecting the Performance of Small and Micro Enterprises in Limuru Town Market of Kiambu County, Kenya. International Journal of Scientific and Research Publications, 4(12), 22-35. 
49.Kamunyu, C. W., \& Theuri, F. S. (2017). Factors Affecting Growth of Women-Owned Small and Medium Enterprises in Kenya: A Survey of Women-Led SMEs in South Coast Ukunda. IOSR Journal of Business and Management (IOSR-JBM), 19(3), 60-66.

50.Kanapathipillai, K., \& Azam, S. M. F. (2019). Women Entrepreneurs Path to Success: An Investigation of the Critical Success Factors in Malaysia. European Journal of Human Resource Management Studies, 2(1), 106-129.

51.Khaleque, A. (2018). Performance of Women Entrepreneurs: Does Access to Finance Really Matter? Eurasian Journal of Business and Economics, 11(21), 23-48.

52.Kim, Y., \& Gao, F. (2013). Does Family Involvement Increase Business Performance? Familylongevity Goals' Moderating Role in Chinese Family Firms. Journal of Business Research, 6(6), 265274.

53.Kimosop, J., Korir, M., \& White, M. (2016). The Moderating Effect of Demographic Characteristics on the Relationship between Strategic Capabilities and Firm Performance in Women-owned Entrepreneurial Ventures in Nairobi, Kenya. Canadian Journal of Administrative Sciences / Revue Canadienne des Sciences de l'Administration, 33(3), 242-256.

54.Koech, B. K. (2015). Factors Influencing Performance of Women-owned Micro and Small Enterprises in Nairobi County in Kenya. The Strategic Journal of Business \& Change Management, 2(2), 17991817.

55.Lee, T., \& Chu, W. (2017). The Relationship between Entrepreneurial Orientation and Firm Performance: Influence of Family Governance. Journal of Family Business Strategy, 8(2), 213-223.

56.Leszczyński, D. (2016). Exploration of Key Success Factors that Influence Business Performance: The Experiences of Women Micro-entrepreneurs from Mazovia Voivodeship of Poland. International Journal of Management and Economics, 10(51), 63-89.

57.Lock, R. \& Lawton Smith, H. (2016). The Impact of Female Entrepreneurship on Economic Growth in Kenya. International Journal of Gender and Entrepreneurship, 8(1), 90-96.

58.Long, T. B., Looijen, A., \& Blok, V. (2018). Critical Success Factors for the Transition to Business Models for Sustainability in the Food and Beverage Industry in The Netherlands. Journal of Cleaner Production, 17(5), 82-95.

59.Lu, K., Zhu, J., \& Bao, H. (2015). High-Performance Human Resource Management and Firm Performance: The Mediating Role of Innovation in China. Industrial Management \& Data Systems, 115(2), 353-382.

60.Mahmood, S. (2013). Microfinance and Women Entrepreneurs in Pakistan. International Journal of Gender and Entrepreneurship, 3(1), 265-274.

61.Mari, M., Poggesi, S., \& De Vita, L. (2016). Family Embeddedness and Business Performance: Evidence from Women-owned Firms. Management Decision, 5(4), 476-500.

62.Meechaiwong, A., Somjai, S., Pol. Gen, \& Girdwicha, N. (2019). Factors Influence Business Performances of Entrepreneurial Female, International Academic Research Conference in Helsinki, Finland, 2(1), 34-37.

63. Mehta, S. (2018). Determinants of Women Entrepreneurs' Performance in Haryana, India. International Journal of Current Microbiology and Applied Sciences, 7(10), 193-202.

64.Miah, J., Khan, S. A., Misto, O. F., \& Karim, R. (2018). Women Entrepreneurship of Sylhet City, Bangladesh: Challenges \& Opportunities. Journal of Management and Organizational Studies, 5(3), 17-28.

65.Mitchelmore, S., \& Rowley. J. (2013). Entrepreneurial Competencies of Women Entrepreneurs pursuing Business Growth, Small Business, and Enterprise Development. International Journal of Business and Management, 20(1), 125-142.

66.Naidu, S., \& Chand, A. (2017). National Culture, Gender Inequality, and Women's Success in Micro, Small, and Medium Enterprises. Social Indicators Research, 13(1), 647-664.

67.Nasri, N., \& Muhammad, S. (2018). Factors Affecting Female Entrepreneurial Intentions in Kabul, Afghanistan. Journal of Economics and Management Sciences, 1(1), 7-16. 
68.Nikina, A., Shelton, L.M., \& LeLoarne, S., (2015). An Examination of how husbands, as Key Stakeholders, Impact the Success of Women Entrepreneurs. Journal of Small Business and Enterprise Development, 22(1), 38-62.

69.Normaizatul Akma Saidia, Nursafeda Abd Rashida, Noraini Mohd Zinb, Hamidah Ramlanc, Norhanizah Joharid \& Mohamad Ramzan Mohamad (2017). Determinants of Women Entrepreneurs' Performance in SMEs. International Symposium \& Exhibition on Business and Accounting, 2(1), 1-6.

70.Olbrich, R., Jansen, H. C., \& Hundt, M. (2017). Effects of Pricing Strategies and Product Quality on Private Label and National Brand Performance. Journal of Retailing and Consumer Services, 3(4), 294-301.

71.Phonthanukitithaworn, C., Ketkaew, C., \& Naruetharadhol, P. (2019). Relevant Factors for Success as an Online Entrepreneur in Thailand. SAGE Open, 9(2), 125-140.

72.Powell, G., \& Eddleston, K. (2013). Linking Family-to-Business Enrichment and Support to Entrepreneurial Success: Do Female and Male Entrepreneurs Experience Different Outcomes? Journal of Business Venturing, 2(8), 261-280.

73.Prasad, V. K., Naidu, G. M., Kinnera Murthy, B., Winkel, D. E., \& Ehrhardt, K. (2013). Women Entrepreneurs and Business Venture Growth: An Examination of the Influence of Human and Social Capital Resources in an Indian Context. Journal of Small Business \& Entrepreneurship, 2(6), 341364.

74.Raheem, F. (2013). Factors Affecting Women Entrepreneurs Business Performance in Pakistan. Journal of Managerial Sciences, 11(4), 11-23.

75.Ratten, V., \& Dana, L.-P. (2017). Gendered Perspective of Indigenous Entrepreneurship. Small Enterprise Research, 2(4), 62-72.

76.Rauth Bhardwaj, B. (2014). Impact of Education and Training on Performance of Women Entrepreneurs: A Study in Emerging Market Context. Journal of Entrepreneurship in Emerging Economies, 6(1), 38-52.

77.Rashid KM, Ngah HC, Mohamed Z, \& Mansor N (2015). Success Factors among Women Entrepreneur in Malaysia. Int. Acad. Res. J. Bus. and Technol. 1(2), 28-36.

78. Rosli, M. M., \& Mahmood, R. (2013). Moderating Effects of Human Resource Management Practices and Entrepreneur Training on Innovation and Small-Medium Firm Performance. Journal of Management and Strategy, 4(2), 60-76.

79.Saad, A. M., Ali, M. H., \& Guza, G. M. (2018). The Influence of Human and Financial Capital on the Performance of Woman Entrepreneurs in Micro and Small Enterprises in State of Perak, Malaysia. Global Journal of Management and Business, 5(1), 65-70.

80.Saidi, N. A., Rashid, N., Ramlan, H., \& Johari, N. (2017). Determinants of Women Entrepreneurs' Performance in SMEs Determinants of Women Entrepreneurs' Performance in SMEs. International Symposium \& Exhibition on Business and Accounting, 2(1), 91-105.

81.Salah, N. (2018). Factors Influencing Women Entrepreneurs' Business Success in Somalia. Research in Business and Management, 5(1), 13-24.

82.Sangolagi, K., \& Alagawadi, M. (2017). Women Entrepreneurs. International Journal of Advancement in Engineering Technology, Management \& Applied Science, 3(1), 216-222.

83.Sathiyabama, P., \& Velmurugan, R. (2019). Challenges Faced by Women Entrepreneurs in Coimbatore District. Jour of Adv Research in Dynamical \& Control Systems, 11(9), 1091-1099.

84.Saunders, M. N., Lewis, P., \& Thornhill, A. (2012). Research Methods for Business Students (6th ed.). England: Pearson Education.

85.Sebikari, K. V. (2014). Entrepreneurial Performance and Small Business Enterprises in Uganda. International Journal of Small Business and Entrepreneurship Research, 2(4), 1-12.

86.Sharma, P. (2013). Women Entrepreneurship Development in India. Global Journal of Management and Business Studies, 3(4), 371-376.

87.Sharma, P., Davcik, N. S., \& Pillai, K. G. (2016). Product Innovation as a Mediator in the Impact of R\&D Expenditure and Brand Equity on Marketing Performance. Journal of Business Research, 69(12), 5662-5669. 
88.Siba, E. (2019). Empowering Women Entrepreneurs in Developing Countries Why Current Programs Fall Short. Africa Growth Initiative, 10(5), 1-9.

89.Singh A, \& Manisha R (2013). Women Entrepreneurs in Micro, Small, and Medium Enterprises. International Journal of Manag. Soc. Sci. Res. (IJMSSR), 2(8), 102-119.

90.Sitharam, S., \& Hoque, M. (2016). Factors Affecting the Performance of Small and Medium Enterprises in KwaZulu-Natal, South Africa. Journal of Problems and Perspectives in Management, 14(2), 203-212.

91.Siwan Mitchelmore Jennifer Rowley, (2013). Entrepreneurial Competencies of Women Entrepreneurs Pursuing Business Growth. Journal of Small Business and Enterprise Development, 20(1), 125-142.

92.Sweida, G.L., \& Reichard, R.J. (2013). Gender Stereotyping Effects on Entrepreneurial Self-efficacy and High-growth Entrepreneurial Intention. Journal of Small Business and Enterprise Development, 20(2), 296-313.

93.Tlaiss, H. (2014). Women's Entrepreneurship, Barriers, and Culture: Insights from the United Arab Emirates. Journal of Entrepreneurship, 2(3), 289-320.

94.Wang, Z., McNally, R., \& Lenihan, H. (2019). The Role of Social Capital and Culture on Social Decision-Making Constraints: A Multilevel Investigation. European Management Journal, 3(7), 222232.

95.Welsh, D. H. B., Kaciak, E., \& Shamah, R. (2018). Determinants of Women Entrepreneurs' Firm Performance in a Hostile Environment. Journal of Business Research, 8(8), 481-491.

96.Wu, J., Li, Y., \& Zhang, D. (2019). Identifying Women's Entrepreneurial Barriers and Empowering Female Entrepreneurship Worldwide: A Fuzzy-set QCA Approach. International Entrepreneurship and Management Journal, 1(5), 905-928.

97.Yusuff, Y. Z., Mohamad, M., Yuhainis, N., \& Wahab, A. (2019). The Influence of General Self-efficacy on Women Entrepreneurs. Academy of Entrepreneurship Journal, 25(2), 1-6.

98.Yusuff, Azizi Abu Bakar, \& Shuhymee Ahmad (2016). Determinant Factors of Women Entrepreneurs' Business Performance: A Conceptual Framework. Journal of Global Business and Social Entrepreneurship (GBSE), 1(1), 55-67.

99.Zeb, Arooj; Jan, Shahid; Ihsan, Anjum; Shah, F. A. A. (2019). Political Factors and Women's Entrepreneurial Performance. Pakistan Journal of Commerce and Social Sciences (PJCSS), 13(1), 165-179.

100. Zeb, A. (2018). Determinants of Successful Women Entrepreneurship in Pakistan. Abasyn Journal of Social Sciences, 2(11), 62-86.

101. Zhou, S. S., Zhou, A. J., Feng, J., \& Jiang, S. (2017). Dynamic Capabilities and Organizational Performance: The Mediating Role of Innovation. Journal of Management \& Organization, 2(2), 117.

102. Zhouqiaoqin Xie YY, Zhang L, \& Suresh K (2013). Factors that Influence the Success of Women Entrepreneur in China: A survey of women entrepreneurs in Beijing. J. of Human and Soc. Sci. 18(3), 83-91. 